\title{
PANDANGAN HAKIM PENGADILAN AGAMA SERANG BANTEN TENTANG PELAKSANAAN ITSBAT NIKAH
}

\author{
Ahmad Sanusi \\ Fakultas Syariah UIN SMH Banten \\ Email : ahmad.sanusi@uinbanten.ac.id
}

\begin{abstract}
Religious Court has authorities to examine and adjudicate cases such as istbat (marriage declaration) and has responsibility to give the best service they can provide for justice seekers on family law matters. This article is try to describe Serang Religious Court Judges' opinions on marriage declaration upon siri marriage. From field research, it is found that the judges argued that marriage declaration is essentially needed to provide an opportunity for couples who were not registered. They conduct the registration/ declaration based on article 7 of the Islamic Law Compilation (KHI) as long as the unregistered marriages fulfilled the whole conditions required based on Islamic marriage law.
\end{abstract}

\section{Keywords:}

Religious Court, marriage legalization, unregistered marriages, judges view

\begin{abstract}
Abstrak
Pengadilan Agama sebagai lembaga yang berwenang memeriksa dan mengadili perkara istbat nikah, tentunya harus memberikan pelayanan yang terbaik bagi pencari keadilan agar permasalahan nikah di bawah tangan yang dilaksanakannya atau karena tidak punya akta nikah dapat segera teratasi, sehingga problematika yang terkait hal-hal keperdataan bagi pasangan suami istri dan anak-anak yang dilahirkan dapat terselesaikan dengan baik. Tulisan ini bertujuan untuk memaparkan pandangan hakim PA Serang tentang Itsbat Nikah karena nikah sirri, termasuk pelaksanaan dan bentuk itsbat nikah yang diitsbatkan karena nikah siri di pengadilan tersebut. Dari hasil penelitian lapangan dapat disimpulkan bahwa hakim Pengadilan Agama Serang berpandangan isbat nikah itu pada prinsipnya memberikan peluang kepada mereka yang tidak mencatatkan pernikahannya dengan dasar Pasal 7 Kompilasi Hukum Islam (HKI), selama syarat dan rukun pernikahan dipenuhi maka dapat diisbatkan selama tidak menyulitkan pihak lain.
\end{abstract}

Kata Kunci:

Pengadilan Agama, Itsbat nikah, Nikah sirri, Pandangan hakim

\section{Pendahuluan}

Membicarakan itsbat nikah, terpikir sesuatu yang kurang pantas terhadap suatu peristiwa hukum yang mendahuluinya dan terkadang hal itu dirasakan sebagai suatu kelalaian mengapa pada waktu itu tidak mendaftarkan perkawinan yang telah dilaksanakan tersebut. Namun kenyataan dalam masyarakat, seolah ada anggapan kalau sudah sah secara agama maka dirasakan cukup, tapi disisi lain ketika berhadapan dengan institusi negara maka dirasakan ada sesuatu yang mengharuskan mereka untuk mau tidak mau harus mentaatinya. 
Mengenai perkara itsbat nikah, belum ada aturan undang-undang yang secara spesifik menjelaskan tentang tata cara pengajuan permohonan itsbat nikah ke Pengadilan Agama. Di dalam Kompilasi Hukum Islam memang terdapat pasal yang menyinggung tentang itsbat nikah, akan tetapi tidak menyebutkan dengan rinci mengenai syarat-syarat untuk mengajukan itsbat nikah, dan hanya menyebutkan pihakpihak yang boleh mengajukan itsbat nikah serta alasan untuk dapat mengajukan itsbat nikah tersebut. Dalam praktek yang terjadi di lingkungan Peradilan, seseorang yang hendak mengajukan itsbat nikah harus mendatangkan dua orang saksi yang telah menyaksikan bahwa telah terjadinya perkawinan tersebut. Namun dalam kewajiban menghadirkan saksi dalam pengajuan itsbat nikah, Undang-Undang tidak membatasi kriteria saksi tersebut. Dengan demikian, saksi itsbat nikah dapat berasal dari keluarga sendiri atau orang lain yang telah menyaksikan suatu perkawinan telah berlangsung.

Pengadilan Agama sebagai lembaga yang berwenang memeriksa dan mengadili perkara istbat nikah, tentunya harus memberikan pelayanan yang terbaik bagi pencari keadilan agar permasalahan nikah di bawah tangan yang dilaksanakannya atau karena tidak punya akta nikah dapat segera teratasi, sehingga problematika yang terkait hal-hal keperdataan bagi pasangan suami istri dan anak-anak yang dilahirkan dapat terselesaikan dengan baik.

Banyak faktor yang menyebabkan seseorang tidak mencatatkan pernikahannya di lembaga pencatatan. Ada yang karena faktor biaya alias tidak mampu membayar biaya administrasi pencatatan, sehingga tidak dicatatkan tetapi tidak dirahasiakan; ada pula yang disebabkan karena takut ketahuan melanggar aturan yang melarang pegawai negeri menikah lebih dari satu kali; dan lain sebagainya. Ada juka pernikahan yang dirahasiakan karena pertimbangan-pertimbangan tertentu, misalnya karena takut mendapat cemohan dari masyarakat, atau pertimbangan- pertimbangan lain yang memaksa seseorang merahasiakan pernikahannya. Setelah dirasa ada kebutuhan yang mendesak, demi kepastian hukum tentang status anaknya maka keduanya (suami istri) mengajukan perkara itsbat nikah ke Pengadilan Agama, kasus seperti itu hal yang biasa. Akan tetapi jika permohonan itsbanikah untuk istri kedua, ketiga, keempat diajukan ke Pengadilan Agama, aturannya menjadikan istri terdahulu menjadi pihak termohon. ${ }^{1}$

Dalam hal bilamana terjadi kondisi seperti tersebut di atas, maka keadaan tersebut menjadi hal yang tidak biasa dan menjadi problem tersendiri dalam proses pengesahan nikah, karena kekhawatiran suami pada umumnya terhadap istri terdahulu jika dimintai persetujuannya untuk itsbat nikah, akan keberatan.

${ }^{1}$ Ninik Rahayu (Komisioner Komnas Perempuan, Sub Komisi Reformasi Hukum dan Kebijakan), Politik Hukum Itsbat Nikah, dalam Musawa Volume 12 Nomor 2 Juli 2013, h. 288, dikutip dari Hamdan Zoelfa, Hukum dan Politik dalam Sistem Hukum Indonesia, (Paradigma Baru Politik Pasca Perubahan UUD 1945), OfficialBlog Hamdan Zoelfa, dari www.journal.uin-suka.ac.id, diakses pada tanggal o5 Juni 2016, jam 16.00 Wib. 
Pengadilan Agama dalam melaksanakan isbat nikah juga tidak sembarangan. Mereka harus menyelidiki apa alasan masyarakat melakukan isbat nikah tersebut. Karena dalam era globalisasi seperti sekarang ini masih ada oknum yang tidak mencatatkan perkawinannya karena mungkin perkawinan yang dilakukan itu bermasalah. Misalnya saja kawin kontrak, kawin sirri, atau melakukan poligami. Padahal dari perkawinan tersebut pasti akan timbul permasalahan yang berkaitan dengan anak dan harta. Jadi mereka harus tetap mencari pengakuan atas perkawinan tersebut untuk memperoleh hak mereka yang berkekuatan hukum.

Itsbat nikah yang dilaksanakan oleh Pengadilan Agama karena pertimbangan mashlahah bagi umat Islam.Itsbat nikah sangat bermanfaat bagi umat Islam untuk mengurus dan mendapatkan hak-haknya yang berupa surat-surat atau dokumen pribadi yang dibutuhkan dari instansi yang berwenang serta memberikan jaminan perlindungan kepastian hukum terhadap masing-masing pasangan suami istri.

Pengadilan Agama dituntut untuk memberikan keputusan dengan pertimbangan yang mengandung kemaslahatan yang lebih besar sesuai dengan rasa keadilan yang tetap berpegang pada peraturan perundang-undangan yang berlaku. Berhubungan dengan hal tersebut Pengadilan Agama terhadap perkara isbat nikah poligami perkara nomor : 190/Pdt.G/2004/PA/Smn memberikan suatu sistem bagaimana pertimbangan Hakim dalam menetapkan perkara isbat nikah poligami, Hakim dalam memutuskan suatu perkara memperhatikan dengan suatu hal dengan objektif, dengan pertimbangan yang matang, mempertimbangkan dengan seksama mana yang harus didahulukan antara mengabulkan atau menolak perkara tersebut berdasarkan pada keadilan dan kemaslahatan dengan tetap memperhatikan nilai-nilai agama dan peraturan perundangan yang berlaku. Terhadap perkara tersebut berdasarkan kemaslahatan bagi keluarga Termohon I dan II, dan dengan pertimbangan syarat-syarat poligami yang tidak terpenuhi seperti yang tercantum Pasal 4 ayat (2) UU No. 1/1974 jo Pasal 57 KHI. Dan Pasal 5 ayat (1) Undang-undang No. 1/ 1974 jo Pasal 58 ayat (1) KHI,beserta surat pernyataan yang membuat isteri dizalimi dikarenakan paksaan suami untuk berpoligami, maka isbat nikah poligami tersebut ditolak. ${ }^{2}$

Isbat Nikah adalah sebuah proses penetapan Pernikahan dua orang Suami isteri yang sebelumnya telah melakukan nikah secara Sirri. Tujuan dari isbat Nikah adalah untuk mendapatkan akta nikah sebagai bukti sahnya perkawinan sesuai dengan peraturan perundang-undangan yang berlaku di Indonesia, misalkan dalam UU No. 1 Tahun 1974 pasal 2 ayat (1) Pasal 2 ayat (2). Pada Dasarnya Pelaksanaan Isbat diperuntukkan pada hal tertentu saja seperti yang telah dijelaskan dalam pasal 7 ayat (1), (2), dan (3) Kompilasi hukum islam, namun fakta dilapangan menunjukkan banyaknya perkara isbat nikah yang masuk di lingkungan Peradilan Agama diluar ketentuan

${ }^{2}$ Neng Djubaidah, Pencatatan Perkawinan Dan Perkawinan Tidak Dicatat Menurut Hukum Tertulis di Indonesia Dan Hukum Islam, (Jakarta: Sinar Grafika 2012). hlm. 223. 
perundang-undangan, misalkan permohonan isbat nikah terhadap pernikahan sirri yang dilakukan setelah terbitnya UU No. 1 Tahun 1974. Oleh sebab itu, dengan penelitian lapangan dan analisis kualitatif, tulisan ini bertujuan untuk memaparkan pandangan hakim PA Serang dalam memutus perkara Isbath nikah terhadap pernikahan sirri yang dilakukan setelah terbitnya UU No. 1 Tahun 1974, serta dampak yang terjadi, dan solusi yang ditawarkan oleh Majelis Hakim Pengadilan Agama Serang dalam menyelesaikan permasalahan tersebut.

Diharapkan tulisan ini dapat memperkuat dan mendukung hasil-hasil penelitian sebelumnya yang berkaitan dengan itsbat nikah, meningkatkan wawasan dan pengetahuan tentang fikih pernikahan kontemporer, serta mengembangkan konsep pemikiran hukum Islam kontemporer dalam Negara moderat yang tertib administrasi.

\section{Terminologi Isbat Nikah}

Isbat nikah berasal dari bahasa Arab yang terdiri dari itsbat dan nikah. kata "itsbat" yang merupakan masdar atau asal kata dari "atsbata" yang memiliki arti "menetapkan", dan kata " nikah" yang berasal dari kata "nakaha" yang memiliki arti "saling menikah", dengan demikian kata "itsbat nikah" memiliki arti yaitu "penetapan pernikahan". ${ }^{3}$ Itsbat nikah dalam bahasa Indonesia dikenal dengan sebutan isbat nikah yang diartikan dengan pengukuhan dan penetapan perkawinan melalui pencatatan dalam upaya mendapatkan pengesahan suatu perkawinan menurut hukum yang berlaku.

Menurut Peter Salim kata itsbat nikah memiliki pengertian penetapan tentang kebenaran nikah. ${ }^{4}$ Itsbat nikah sebenarnya sudah menjadi istilah dalam Bahasa Indonesia dengan sedikit revisi yaitu dengan sebutan isbat nikah. Menurut Kamus Besar Bahasa Indonesia, isbat nikah adalah penetapan tentang kebenaran (keabsahan) nikah. Itsbat nikah adalah pengesahan atas perkawinan yang telah dilangsungkan menurut syariat agama Islam, akan tetapi tidak dicatat oleh KUA atau PPN yang berwenang (Keputusan Ketua Mahkamah Agung RI Nomor KMA/032/SK/2006 tentang Pedoman Pelaksanaan Tugas dan Administrasi Pengadilan).

Itsbat nikah di Pengadilan Agama oleh para pemohon digunakan sebagai alas hukum untuk mencatatkan perkawinannya pada Pegawai Pencatat Nikah KUA Kecamatan, dan dari Kecamatan akan mengeluarkan Buku Kutipan Akta Nikah sebagai bukti otentik bahwa suatu perkawinan telah tercatat, untuk selanjutnya Buku Kutipan Akta Nikah itu akan digunakan oleh yang bersangkutan untuk mengurus Akta Kelahiran Anak pada Kantor Catatan Sipil yang mewilayahinya dengan dilampiri penetapan itsbat nikah oleh Pengadilan Agama.

Pengadilan Agama dengan itsbat nikah mempunyai andil dan kontribusi yang sangat besar dan penting dalam upaya memberikan rasa keadilan dan kepastian serta

\footnotetext{
${ }^{3}$ Ahmad Warsono Munawir ,Al-Munawir Kamus Arab-Indonesia, hal. 145.

${ }^{4}$ Departemen Pendidikan dan Kebudayaan, Kamus Besar Bahasa Indonesia, hal. 339.
} 
perlindungan hukum bagi masyarakat. Mereka yang selama ini tidak memiliki Kartu Keluarga karena tidak mempunyai Buku Nikah, setelah adanya penetapan itsbat nikah oleh Pengadilan Agama mereka akan mudah mengurus Kartu Keluarga dan Akta Kelahiran anak-anak mereka sehingga sudah tidak kesulitan untuk masuk sekolah.

Berdasarkan ketentuan Pasal 2 Ayat 1 UUP dan penjelasannya ini, dapat diketahui bahwa patokan untuk mengetahui suatu perkawinan sah adalah hukum masing-masing agama dan kepercayaan para pihak serta ketentuan perundangundangan yang berlaku sepanjang tidak bertentangan atau tidak ditentukan lain dalam Undang Undang Perkawinan. Ketentuan pencatatan perkawinan diatur dalam Pasal 2 Ayat (2) Undang-Undang Nomor 1 Tahun 1974 tentang Perkawinan bertujuan agar terjamin ketertiban perkawinan bagi masyarakat Islam (Pasal 5 Ayat (2) Kompilasi Hukum Islam) dan untuk menjamin ketertiban hukum (legal order) sebagai instrumen kepastian hukum, kemudahan hukum, di samping sebagai bukti otentik adanya perkawinan.

Pencatatan perkawinan merupakan salah satu bentuk intervensi pemerintah atau negara untuk melindungi dan menjamin terpenuhinya hak-hak sosial setiap warga negara, khususnya pasangan suami istri, serta anak-anak yang lahir dari perkawinan itu.Pasal 2 ayat (2) menyebutkan bahwa tiap-tiap perkawinan dicatat menurut peraturan perundang-undangan yang berlaku. Pencatatan perkawinan akan menimbulkan kemaslahatan umum karena dengan pencatatan ini akan memberikan kepastian hukum terkait dengan hak-hak suami/isteri, kemaslahatan anak maupun efek lain dari perkawinan itu sendiri. Perkawinan yang dilakukan di bawah pengawasan atau di hadapan Pegawai Pencatat Nikah/Kantor Urusan Agama akan mendapatkan Akta Nikah sebagai bukti telah dilangsungkannya sebuah perkawinan.

Akta Nikah merupakan akta autentik juga berfungsi untuk memperoleh kepastian hukum sebuah perkawinan.Kepastian hukum sendiri disebut juga dengan istilah principle of legal security dan rechtszekerheid.Kepastian hukum adalah perangkat hukum suatu negara yang mampu menjamin hak dan kewajiban setiap warga negara. Kepastian hukum (rechtszekerheid) juga diartikan dengan jaminan bagi anggota masyarakat, bahwa semuanya akan diperlakukan oleh negara/penguasa berdasarkan peraturan hukum, tidak dengan sewenang-wenang. Karena Akta Nikah tersebut dibuat oleh dan di hadapan Pegawai Pencatat Nikah sebagai pejabat yang berwenang untuk melakukan pencatatan perkawinan, dibuat sesuai dengan bentuk yang ditetapkan oleh Peraturan Pemerintah Nomor 9 Tahun 1975 dan dibuat di tempat Pegawai Pencatat Nikah/Kantor Urusan Agama tersebut melaksanakan tugasnya.

\section{Nikah Siri}

Kata "siri" dalam istilah nikah siri berasal dari bahasa Arab, yaitu "sirrun" yang berarti "rahasia". Melalui akar kata ini, nikah siri berarti sebagai nikah yang dirahasiakan, berbeda dengan nikah pada umumnya yang dilakukan secara terang-terangan (jahri). 
Nikah siri bisa didefinisikan sebagai "bentuk pernikahan yang dilakukan hanya berdasarkan aturan (hukum) agama dan atau adat istiadat, tetapi tidak diumumkan kepada khalayak umum, dan juga tidak dicatatkan sacara resmi pada kantor pegawai pencatat nikah, yaitu Kantor Urusan Agama (KUA) bagi yang beragama islam dan Kantor Catatan Sipil (KCS) bagi yang beragama non-islam". Definisi ini sudah cukup menggambarkan perbedaan antara nikah siri dengan nikah pada umumnya.

Menurut Happy Santoso di Indonesia, nikah siri mulai berkembang sejak dekade 1970-an, yang awalnya ditandai dengan realitas yang terjadi di daerah Kalimantan. Ketika itu pemerintah Indonesia memberikan peluang bagi perusahaan-perusahaan asing yang akan menebang dan mengelola kayu. Bisnis usaha ini membutuhkan banyak pekerja, tidak hanya tenaga kerja dalam negeri, tetapi juga mencakup tenaga kerja asing yang datang sendiri-sendiri tanpa disertai keluarganya. Keadaan ini menyebabkan kebutuhan biologis mereka yang perlu "disalurkan", mengingat istri-istri mereka berada jauh di negaranya masing-masing. Sebagai salah satu usaha memenuhi hasrat itu, mereka mendekati perempuan-perempuan penduduk sekitar pabrik.Tidak sedikit dari mereka yang berkeinginan menikahi perempuan-perempuan itu. Ternyata pernikahan itu tidak mudah dilakukan karena harus memenuhi prosedur hukum yang tidak mudah, mengingat mereka berada di jalur hukum yang berbeda dan juga kebanyakan pendatang asing tersebut menganut agama yang berbeda pula dengan kebanyakan penduduk setempat. Jalan yang mungkin ditempuh adalah melakukan pernikahan secara siri (bawah tangan) melalui mediasi sejumlah ulama atau kiai di daerah itu yang berfatwa bahwa akad nikah tetap sah meskipun tidak dicatatkan di KUA setempat. Nikah siri juga merak terjadi akibat kondisi penduduk yang masih dalam kondisi kekurangan dan juga didukung oleh persepsi perempuan-perempuan setempat yang menganggap jika bisa menikah dengan tenaga kerja asing, kehidupan ekonomi mereka dapat lebih meningkat.

Di kalangan ulama dan masyarakat muslim sendiri, terdapat perbedaan pandangan tentang nikah siri, ada yang menghalalkan, mengharamkan, hingga ada yang berada di posisi tengah-tengah. Pebedaan pandangan tersebut sangat lumrah terjadi karena masing-masing pihakberargumen dengan interpretasinya sendiri.Oleh karena itu, yang penting adalah jangan sampai ada pihak yang berusaha memonopoli tafsir sesuai dengan hawa nafsunya demi memenuhi maksud dan kepentingannya semata.Tafsir didalam islam didasarkan pada sejumlah argumen yang dan rujukan, baik berasal dari Alquran, hadis, ijtihad, ijma', maupun qiyas.

Nikah siri yang dilatarbelakangi dengan tujuan berpoligami (beristri lebih dari satu) juga perlu diluruskan. Pernikahan siri yang meskipun dilangsungkan dengan adanya wali dan dua saksi dan diketahui oleh orang lain, tetapi istri pertamanya tidak diberitahu terlebih dahulu dengan alasan-alasan tertentu, maka pernikahan model itu perlu dipertanyakan. Secara syariat, prosesi pernikahan adalah sah karena memenuhi syarat dan rukunnya, tetapi sejatinya orang yang berpoligami harus mendapat izin dari istri 
pertamanya terlebih dahulu. Berdasarkan hukum positif, tindakan demikian dapat menciderai dan membatalkan status sahnya pernikahan.

\section{Permohonan Isbat Nikah ke Pengadilan Agama Serang}

Sebagaimana Pengadilan Agama lainnya, maka Pengadilan Agama Serang melaksanakan kewajibannya sesuai dengan perundang-undangan yang berlaku. Salahsatu perkara yang ada diperiksa adalah perkara Itsbat Nikah.

Pihak yang bisa mengajukan isbat nikah adalah: (1) Suami, (2) Istri, (3) Ahli waris dari pasangan suami istri, dan (4) Pihak yang berkepentingan dengan pernikahan tersebut.

Hal-hal yang bisa diajukan isbat nikah sesuai dengan pasal 7 ayat (3) KHI, yaitu: (a) adanya perkawinan dalam rangka penyelesaian perceraian, (b) hilangnya akta nikah, (c) adanya keraguan tentang sah atau tidaknya salah satu syarat perkawinan, d. adanya perkawinan yang terjadi sebelum berlaku UU Nomor 1 Tahun 1974, dan (e) perkawinan yang dilakukan oleh mereka yang tidak mempunyai halangan perkawinan menurut UU Nomor 1 Tahun 1974. 3.

Adapun prosedur pengajuan permohonan isbat nikah di Pengadilan Agama Serang adalah sebagai berikut:

a. Mendaftar ke Kantor Pengadilan Agama Ketika mendaftar, pemohon membuat surat permohonan isbat nikah. Surat permohonan ini dibuat sendiri oleh pemohon atau kuasa hukumnya.Apabila tidak bisa membuat, pemohon bisa datang ke petugas Pra Meja untuk memberitahukan isi permohonannya kepada petugas. Kemudian petugas akan membuatkan surat permohonan isbat nikah (seperti terlampir) sesuai keterangan dari pemohon. Selain itu pemohon juga harus membawa surat-surat yang diperlukan sebagai bukti, misalnya surat keterangan dari KUA bahwa pernikahannya belum dicatat atau kutipan akta nikahnya hilang, Kartu Tanda Penduduk (KTP), dan Kartu Keluarga (KK). Setelah membuat surat permohonan, pemohon membawa surat permohonan tersebut ke Meja I untuk ditaksir biaya perkaranya. Kemudian petugas akan membuat Surat Kuasa Untuk Membayar (SKUM).

b. Membayar panjar biaya perkara Pembayaran panjar biaya perkara ke kasir di Meja II. Petugas kasir akan memcatat panjar biaya perkara yang diterima dalam jurnal keuangan. Setelah itu petugas akan memberikan Surat Permohonan kepada calon pemohon tadi. Kemudian pemohon membawa Surat Permohonan tersebut ke Meja III untuk mendapatkan nomor perkara, nomor ini terdiri dari 4 digit angka yaitu: nomor/Pdt.P/ tahun/ kode pengadilan yaitu PA.Sal. Nomor perkara ini akan dicatat di buku induk Register Perkara dan berkas perkara tersebut diserahkan kepada wakil panitera untuk penentuan hari sidang, penentuan majelis hakim, dan penunjukan panitera pengganti. 
c. Menunggu panggilan sidang Pengadilan akan mengirim Surat Panggilan kepada pemohon ke alamat yang tertera dalam surat permohonan yang dibuat oleh pemohon.

d. Menghadiri persidangan Setelah menerima Surat Panggilan dari Pengadilan, pemohon diharapkan hadir pada persidangan sesuai waktu dan tempat yang telah ditentukan oleh Pengadilan. Adapun agenda persidangannya adalah mediasi, pembacaan permohonan, jawaban, replik, duplik, pembuktian, kesimpulan, dan putusan. Dalam persidangan tidak menutup kemungkinan pemohon diminta untuk menghadirkan saksi untuk pembuktian. Menerima penetapan dari Pengadilan Agama Jika Pengadilan mengabulkan permohonan pemohon, maka Pengadilan akan mengeluarkan Penetapan Isbat Nikah. Dan jika permohonan tidak diterima, maka pernikahan pemohon dianggap tidak sah.

\section{Pembahasan}

Berdasarkan data yang dikumpulkan dan wawancara yang dilakukan, penulis melihat maraknya Itsbat nikah yang diajukan ke pengadilan agama Serang adalah lebih banyak karena faktor ekonomi karena untuk melakukan secara resmi di kantor urusan agama memerlukan biaya yang cukup tinggi kurang lebih lima ratus ribu rupiah, sehingga bagi masyarakat yang berpenghasilan rendah, mereka akan merasa terbebani dengan biaya mahal tersebut. Selain faktor ekonomi, hal lain yang menyebabkan masyarakat nikah siri adalah karena kurangnya sosialisasi arti penting mencatat pernikahan. Bagi mereka yang tidak mengerti dan mengetahui arti penting pencatat nikah menganggap bahwa nikah tidak perlu dicatat cukup sesuai agama Islam saja. Padahal dengan tidak dicatatnya pernikahan mereka, terdapat permasalahan yang akan muncul di kemudian hari seperti anak yang dilahirkan oleh orang tua yang pernikahannya tidak dicatatkan akan sulit mendapatkan akta lahir; atau ketika suami meninggalkan isteri tanpa kabar berita selama bertahun-tahun, maka isteri tidak dapat mengajukan haknya ke lembaga yang berwenang menangani masalah tersebut (pengadilan agama) karena pernikahannya tidak memiliki bukti otentik berupa Akta Nikah, sehingga status pernikahannya tersebut secara hukum tidak legal dan majelis Hakim tidak akan dapat berbuat apa-apa terhadap kasus pernikahan semacam itu.

Selama kurun waktu 2016, Pengadilan Agama Serang menerima permohonan itsbat nikah sebanyak 366 perkara, dengan rincian terpapar dalam tabel 1.

Tabel 1.

Perkara Itsbat Nikah di Pengadilan Agama Serang Tahun 2016

\begin{tabular}{|l|c|c|c|}
\hline \multicolumn{1}{|c|}{ Bulan } & $\begin{array}{c}\text { Perkara } \\
\text { masuk }\end{array}$ & $\begin{array}{c}\text { Perkara } \\
\text { Putus }\end{array}$ & Ket \\
\hline Januari & 69 & 28 & \\
\hline Februari & 28 & 64 & Sisa bulan Lalu 65 \\
\hline
\end{tabular}




\begin{tabular}{|l|c|c|l|}
\hline Maret & 24 & 21 & \\
\hline April & 27 & 4 & \\
\hline Mei & 53 & 15 & \\
\hline Juni & 41 & 26 & \\
\hline Juli & 74 & 12 & \\
\hline Agustus & 38 & 49 & Sisa bulan lalu 170 \\
\hline September & 37 & 20 & \\
\hline Oktober & 32 & 23 & Sisa perkara bulan lalu 173 \\
\hline Jumlah & 366 Perkara Itsbat Nikah \\
\hline
\end{tabular}

Sumber : Pengadilan Agama Serang

Banyaknya kasus itsbat nikah yang diajukan masyarakat Serang menandakan mulai menyadarinya masyarakat akan pentingnya pencatatan nikah, hal ini tidak luput dari kerja keras pengadilan agama Serang dalam mensosialisasikan program pentingnya pencatatan nikah bekerjasama dengan berbagai elemen baik pemerintah maupun para ulama.

Munculnya ketentuan itsbat nikah tidak bisa dipisahkan dari ketentuan keharusan adanya pencatatan perkawinan, sebagaimana diamanatkan Undang-undang. Landasan hukum itsbat nikah, kalau dianalisi dibedakan menjadi:

1. Itsbat nikah terhadap perkwinan yang terjadi sebelum berlakunya Undangundang no.1 tahun 1974. Landasan hukumnya Undang-undang no. 7 tahun 1989, penjelasan pasal 49 ayat (2) angka 22 jo Undang-undang no.3 tahun 2006 penjelasan pasal 29 huruf a angaka 22, yang kemudian dipertegas dengan pasal 7 ayat (3) huruf d kompilasi hukum Islam.

2. Itsbat nikah terhadap perkawinan yang tidak dicatat yang terjadi sebelum atau sesudah berlakunya Undang-undang ni.1 tahun 1974. Landasan hukumnya dari pemahaman pasal 7 ayat (2) dan (3) Intruksi presiden nomor 1 tahun 1991 tentang kompilasi hukum Islam.

Munculya ketentuan Itsbat Nikah berkaitan dengan masalah status pencatatan perkawinan. Ada dua pandangan mengenai masalah status pencatatan perkawinan tersebut. Pandangan pertama yaitu pendapat yang menyatakan bahwa pencatatan perkawinan hanya merupakan persyaratan administratif, tidak merupakan persyaratan sahnya suatu perkawinan, jadi pencatatan perkawinan hanya proses untuk mendapatkan suatu bukti bahwa telah terjadi perkawinan yang dilakukan oleh seseorang. Adapun pandangan kedua menyatakan bahwa pencatatan perkawnan menjadi syarat sah perkawinan.

Menurut pendapat pertama sahnya suatu perkawinan hanya didasarkan pada ketentuan agama yang dipeluk oleh orang yang akan melangsungkan perkawinan, sebagaimana disebutkan Pasal 2 ayat (1) Undang-undang No.1 tahun 1974 tentang 
perkawinan. Pencatatan perkawinan hanya bersifat administratif dan berada di luar unsur keabsahan perkawinan tersebut. Sahnya suatu perkawinan sesaat setelah terjadinya ijab qabul antara wali nikah dengan calon pengantin pria.

Sedang argumentasi pendapat kedua yang mengatakan bahwa pencatatan merupakan bagian dari sahnya perkawinan, terutama dengan alasan kepastian hukum tentang bukti danya perkawinan tersebut. Dalam pandangan ini ayat (1) dan ayat (2) dari Pasal 2 Undang-undang No.1 Tahun 1974 merupakan satu kesatuan yang tidak dapat dipisahkan. Lebih jauh, alasan pandangan ini dihubungkan dengan manfaat kemaslahatan yang didapat dengan pencatatan tersebut, dengan mengacu kepada maslahat mursalah atau untuk menghindari akibat yang merugikan/tidak diinginkan (sad aldzari'ah). Ada juga pandangan yang meletakkan pencatatan perkawinan sebagai salah satu rukun yang harus dipenuhi untuk sahnya suatu akad nikah. ${ }^{5}$

Selanjutnya untuk menentukan mana yang terbaik dari dua pandangan di atas, maka perlu ada kejelasan dalam bentuk peraturan perundang-undangan dari pemerintah dengan didukung oleh semua pihak untuk memasukan pencatatan perkawinan sebagai bagian dari sahnya suatu perkawinan atau pencatatan perkawinan hanya bersifat administratif dengan tetap mempertahankan kemungkinan munculnya Itsbat Nikah.

Penulis melihat dari segi tujuan diajukannya itsbat nikah dari data di atas bahwa alasan untuk membuat akte kelahiran, maka hal itu terlihat bahwa masyarakat Serang sudah mulai mementingkan hal-hal yang berkaitan dengan administrasi sipil modern. Dengan demikian kesadaran masyarkat akan pentingnya administrasi perkawinan sudah lebih diperhatikan.

\section{Simpulan}

Dari tulisan di atas dapat disimpulkan bahwa hakim Pengadilan Agama Serang berpendapat bahwa isbat nikah itu pada prinsipnya memberikan peluang kepada mereka yang tidak mencatatkan pernikahannya. Artinya, keabsahan tentang nikah mungkin ada pengecualian yang semula dibatasi hanya terjadi sebelum tahun 1974 tapi dengan Pasal 7 KHI ini diterjemahkan oleh hakim yakni semua pernikahan baik sebelum maupun sesudah tahun 1974, hal itu selama memenuhi syarat dan rukun pernikahan bisa diisbatkan selama tidak menyulitkan pihak lain. Dasar pertimbangan hakim dalam mengabulkan isbat nikah karena pernikahan sirri menurutnya dibolehkan selama tidak merugikan pihak lain. Oleh karena itu harus diajukan dengan cara ada lawan (Contentiosa) dan tetap dilakukan dengan cara hati-hati untuk menjaga hak-hak istri pertama dan hak anak,. Putusan hakim berorientasi pada prinsip Agama bukan karena undangundang jadi sementara undang-undang itu hanya administratif.

\footnotetext{
${ }^{5}$ Usman Suparman, Kepastian Hukum Itsbat Nikah terhadap Status Perkawinan, Status Anak dan Status Harta Perkawinan, makalah disampaikan dalam Acara penelitian yang dilaksanakan oleh Pusat Penelitian dan Pengembangan Mahkamah Agun RI, tanggal 14-16 Mei 2012 bertempat di Hotel Le Dian Serang Banten, h.5-6.
} 
Pelaksanaan Itsbat nikah di Pengadilan Agama Serang adalah sama dengan pengadilan-pengadilan agama lainnya yaitu sesuai dengan prosedur yang diatur dalam peraturan perundang-undangan yang berlaku yaitu dimana pemohon mendaftar ke Kantor Pengadilan Agama Ketika mendaftar, pemohon membuat surat permohonan isbat nikahk dan membawanya ke Meja I untuk ditaksir biaya perkaranya. Kemudian petugas akan membuat Surat Kuasa Untuk Membayar (SKUM). Membayar panjar biaya perkara Pembayaran panjar biaya perkara ke kasir di Meja II. Mendapatkan nomor perkara di Meja III, dan kemudian menunggu panggilan sidang Pengadilan, menghadiri persidangangan setelah menerima surat panggilan dari pengadilan. Menerima penetapan dari Pengadilan Agama Jika Pengadilan mengabulkan permohonan pemohon, maka Pengadilan akan mengeluarkan Penetapan Isbat Nikah. Jika permohonan tidak diterima, maka pernikahan pemohon dianggap tidak sah. Berdaskan penelusuran informasi dan wawancara, diketahui bahwa Pengadilan Agama Serang menetapkan Itsbat nikah dari perkawinan yang sudah memenuhi rukun dan syarat nikah namun tidak dicatatkan karena tidak mampu sehingga pengajuan Itsbat Nikahnya juga bebas biaya.

\section{Daftar Pustaka}

\section{Buku}

Amien, Mawardi. 2012. Kepastian Hukum Isbat Nikah terhadap Status Perkwinan, Status Anak dan Status Harta Perkawinan. Pusat Penelitian dan Pengembangan Mahkamah Agung RI, 14-16, Mei 2012.

Departemen Pendidikan dan Kebudayaan, Kamus Besar Bahasa Indonesia

Djubaidah, Neng. 2012. Pencatatan Perkawinan dan Perkawinan Tidak Dicatat Menurut Hukum Tertulis di Indonesia dan Hukum Islam, Jakarta: Sinar Grafika.

Harahap, M. Yahya. 1994. Hukum Acara Perdata, Cet. Kedua,Jakarta: Sinar Grafka.

Hasan, Damsyi. 1997. Permasalah Isbat Nikah (Kajian terhadap Pasal 2 UU. No. 1 Tahun 1974 dan pasal 7 KHI). Artikel dalam Mimbar Hukum, No. 31, Jakarta: Al-Hikmah dan Ditbinbapera Islam.

Munawir, Ahmad Warsono. 1984. Al-Munawir Kamus Arablndonesia, Yogyakarta : Pondok Pesantren Munawir.

Rahayu, Ninik. 2013 . (Komisioner Komnas Perempuan, Sub Komisi Reformasi Hukum dan Kebijakan), Politik Hukum Itsbat Nikah, dalam Musawa Volume 12 Nomor 2 Juli 2013 .

Soenarjo, R.H.A. 2007. Alquran dan Terjemahnya, Jakarta: Departemen Agama RI.

Suparman,Usman. 2012. Kepastian Hukum Itsbat Nikah terhadap Status Perkawinan, Status Anak dan Status Harta Perkawinan, Pusat Penelitian dan Pengembangan Mahkamah Agung RI. 
174 | Asy-Syari'ah Vol. 20 No. 2, Desember 2018

Zoelfa, Hamdan. 2016. Hukum dan Politik dalam Sistem Hukum Indonesia, (Paradigma Baru Politik Pasca Perubahan UUD 1945), Official Blog Hamdan Zoelfa, dari www.journal.uin-suka.ac.id, diakses pada tanggal o5 Juni 2016, jam 16.00 wib.

\section{Perundang-undangan}

Undang-undang Nomor 23 tahun 2006 Tentang Administrasi Kependudukan Undang-Undang Nomor 25 Tahun 1999 Tentang Otonomi Daerah. Undang-Undang. No.4 Tahun 2004 Tentang Kekuasaan Kehakiman 